\title{
Mollusks From the
}

Pepper Shale Member of

the Woodbine Formation

McLennan County, Texas

GEOLOGICAL SURVEY PROFESSIONAL PAPER 243-E

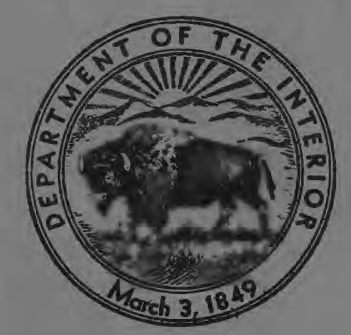




\section{Mollusks From the}

Pepper Shale Member of the Woodbine Formation

\section{McLennan County, Texas} By LLOYD WILLIAM STEPHENSON SHORTER CONTRIBUTIONS TO GENERAL GEOLOGY, 1952, PAGES 57-68

GEOLOGICAL SURVEY PROFESSIONAL PAPER 243-E Descriptions and illustrations of new species of fossils of Cenomanian age

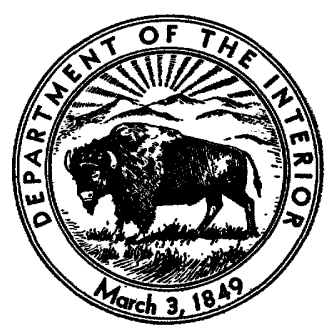




\section{UNITED STATES DEPARTMENT OF THE INTERIOR}

Douglas McKay, Secretary

\section{GEOLOGICAL SURVEY}

W. E. Wrather, Director

For sale by the Superintendent of Documents, U. S. Government Printing Office Washington 25, D. C. - Price 25 cents (paper cover) 


\section{CONTENTS}

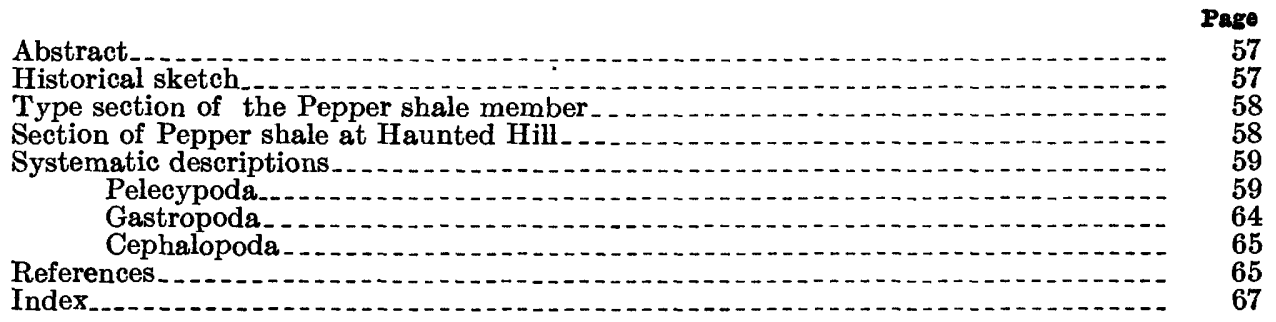

\section{ILLUSTRATIONS}

Plate 13. Molluscan fossils, mainly from the Pepper shale............... Following index 


\title{
MOLLUSKS FROM THE PEPPER SHALE MEMBER OF THE WOODBINE FORMATION, MCLENNAN COUNTY, TEXAS
}

\author{
By Lloyd Wirliam Stephenson
}

\begin{abstract}
This paper records an assemblage of molluscan fossils from the Pepper shale member of the Woodbine formation at a locality known as Haunted Hill, 3.5 miles northwest of Moody, McLennan County, Texas. The assemblage includes the following four species previously described by me from the Woodbine formation: Anomia ponticulana?, Fulpia pinguis, Cyprimeria patella, and "Corbula" hillensis. One species common to the Lewisville member of the Woodbine, previously described as Exogyra sp., is here given the new specific name, Exogyra aquillana. The following six additional new species are described: Breviarca (Sanoarca) spiritalis, Breviarca (Sanoarca) calciana, Cyclorisma nodana, Sinonia lozoi, Parmicorbula moodiana, and Anchura umbrana. One new variety, Turritalla shuleri pepperana, is described. The genus Baculites, not previously recorded from the Woodbine formation, is represented by a fragment of a small smooth unidentified species.

The evidence afforded by this assemblage confirms the conclusion that the Pepper shale member is the southward extension of the Woodbine formation, and is probably the extension of the Lewisville member of that formation.
\end{abstract}

\section{HISTORICAL SKETCH}

The stratigraphic unit from which the fossils described in this paper were obtained was named the Pepper formation by W. S. Adkins in 1933 (Univ. of Texas Bull., 3232, pp. 239, 270, 417-422). This shale unit lies between the top of the Comanche series and the flaggy limestones and dark shales that form the base of the Eagle Ford shale (Gulf series) of Late Cretaceous age. It crops out in a narrow belt extending from McLennan County, Texas, south ward through Bell and Williamson Counties to Travis County. The unit had been known to earlier geologists, some of whom considered it a southward extending sbale facies of the Woodbine formation, and others a basal member of the Eagle Ford shale. The thickness of the unit in central McLennan County is 75 feet or less, from which area southward it gradually becomes thinner and finally pinches out by overlap in Travis County south of Austin.
My attention was first called to this unit by Mr. R. L. Cannon, in 1926 (oral communication). He informed me that he had traced a Woodbine-like clay or shale from Hill County, where it was generally recognized as belonging to the Woodbine formation, southward through McLennan, Bell, and Williamson Counties, to the vicinity of Austin in Travis County. Acting c $\eta$ this information I visited localities in Hill, McLennan, and Bell Counties in 1926, and was able to confirm th 9 presence of the Woodbine-like shale unit between tl:? Buda limestone below and the undoubted Eagle Ford shale and interbedded flaggy limestone above. I did not at the time have an opportunity to restudy th ? section in Travis County. However, on a visit in 1928 I noted several feet of dark noncalcareous Woodbinslike clay forming the base of the section (mainly Eagle Ford) which intervenes between the Buda limestone below and the Austin chalk above on Bouldin Creek south of Colorado River at Austin. (Stephenson, 1927, pp. 3, 4.) In the Guide Book of the 1951 Field Trip of the East Texas Geological Society (Cretaceous of Waco, Texas Area, p. 155), the thickness of this clay, designated Pepper, is given by Adkins and Lozo as 3.4 feet.

The shale composing this unit is only meagerly fosiliferous and the few macrofossils heretofore found in it are poorly preserved. Adkins listed several genera of pelecypods, gastropods and ammonites, preserved as delicate impressions, from the type locality of the unit, but he did not consider them diagnostic of exact age (1933; p. 419).

The late Helen Jeanne Plummer (in Adkins, 1933, pp. 419, 420) identified arenaceous Foraminifera from the lower part of the type section of the Pepper shale, belonging to the genera Ammobaculites, Ammodiscus, and Reophax. She says,

These species have no relation to those of the Grayson or Del Rio formations, but are similar to species in the Eagle Ford and other Upper Cretaceous faunal groups. I feel no hesitancy in referring this shale to the Upper Cretaceous series. 
In 1946 Alfred R. Loeblich, Jr., described eleven new species of arenaceous Foraminifera from the type locality of the Pepper shale on Bird Creek, a small tributary of Leon River, 4 miles east-northeast of Belton, Bell County, about 500 feet southeast of the BeltonTemple highway (U. S. 81). Loeblich says (pp. 132133) :

Environment.-The writer believes these sediments were deposited in shallow waters of low salinity, because of the presence of abundant siderite and limonite concretions, the presence of large numbers of reworked calcareous forms, the absence of any indigenous calcareous Foraminifera in the type Pepper, the small size of the arenaceous species, the large amount of organic matter in some of the samples, and the limited megafauna, which consists only of mollusks and worms.

Correlation.-The present fauna consists entirely of new species, and hence cannot settle the question of the correlation of the Pepper formation, but perhaps can be used for comparison when the microfauna of the Woodbine is better known.

At the time Loeblich's paper was published he knew of the presence of this assemblage of arenaceous Foraminifera only at the type locality of the Pepper shale, but he informs me that at a later time he found the same assemblage in the few feet of dark noncalcareous shale immediately overlying the Buda limestone in the Bouldin Creek section south of Austin.

In recent years the age and stratigraphic relationships of the Pepper shale have been more critically studied in the Waco area (including parts of Bell, McLennan and Hill Counties) by Adkins and Frank E. Lozo, and the results of their field and laboratory studies are recorded in a paper published as part of " $\mathbf{A}$ Symposium for the 1951 Field Trip Sponsored by the East Texas Geological Society" (1951, pp. 101-161). It was my privilege to participate in this field trip, which was held May 3 to 5, 1951. The fossils described in the present paper (U. S. G. S. Coll. 23634) were collected by me during the course of the trip at the locality designated "Haunted Hill" by Adkins and Lozo (pp. 134, $135)$.

As a result of their study of the Pepper shale Adkins and Lozo interpreted this unit to be a southward extending shale facies of the Lewisville member of the Woodbine formation. They summarize their conclusions in the following words (1951, p. 116) :

In the area north of the Brazos, strata of porous and crumbly to friable, locally indurated, ferruginous sandstones occur, alternating with Pepper-type black, noncalcareous shales. Southward these sandstones thin and disappear laterally within the body of the shale formation, which is composed thereafter entirely of Pepper facies. This is a noncalcareous, noncarbonaceous (except for ferrous carbonate and thin shells), black, locally glistening shale which contains pyrite and on the outcrop develops gypsum, celestite, siderite, jarosite, and other minerals. The outcrop is poor in soil and vegetation. The fossil zonation is spotty, but at levels fossils occur, as shale ammonites at Alljgator Creek; in fossiliferous limy seams at Haunted Hill.

\section{TYPE SECTION OF THE PEPPER SHALE MEMBER}

The type section of the Pepper shale member of the Woodbine formation is in small northwest-facing bluffs of Bird Creek, a small tributary of Leon River, 500 feet southeast of the Belton-Temple highıway (TJ. S. 81), about 4 miles east-northeast of Belton, Bell County. The member was named from nearby Pepper Creek. The following description of the type section is adapted from the description of the measured type section given by Adkins and Lozo (p. 130).

\section{Section on Bird Creek, 4 miles east-northeast of Belton, Bell County, Texas}

Gulf series :

Eagle Ford shale:

Limestone, wavy-bedded, yellowish-brown, massive to platy and thin-bedded, witr a thin bed of bentonite near the middle; locally with ammonites and other mol-

lusks, in part fragmentary
Shale, black, fissile, slightly calcareous, with abundant globigerinids and other shells_-_- 1.5 Unconformity

Woodbine formation (Pepper shale member) :

Shale, purplish-black, noncalcareous, with silenite crystals, and with yellow jarosite crystals, films and streaks in weathered perts of the shale; contains arenaceous foraminifers and thin nacreous shells and impressions of mollusks

Shale, gypsiferous, with many euhedral sle. nite crystals______-_ 0.6

Clay, sandy, carbonaceous, gypsiferous, with quartz and phosphate pebbles, fish remains, lignitized wood and reworked Del Rio [ric] fossils

Unconformity

Comanche series :

Grayson marl (formerly Del Rio clay) :

Clay, gray, massive, calcareous, fossiliferous-- 1.5

Limestone, gray, soft, gritty, clayey_-...-_- 0.3

Clay or marl, exposed downstream-_-_--- $25+$

Tota1

$54+$

\section{SECTION OF THE PEPPER SHALE MEMBER AT HAUNTED HILL}

Haunted Hill is a low hill at the south end of a series of low hills, known as Moody Hills, about 3.5 miles northwest of Moody, McLennan County. T*a Pepper shale is well exposed in a bare area on the upper slope of Haunted Hill; neither the base nor the top of the member are seen in the exposure. The description of the shale given below is essentially a copy of that given by Adkins and Lozo, who measured in detail the beds exposed in the slope of the hill. They treated the shale as a formation of the Woodbine group. 
Incomplete section of Pepper shale exposed in the upper slope of Haunted Hill, 3.5 miles northwest of Moody, McLennan County, Texas

Woodbine formation (Pepper shale member) : Feet Shale, bluish-black, lustrous, jarositic and selenitic... Siderite concretions, small, reddish-brown, flat, oral Shale, bluish-black, lustrous, jarositic and selenitic.Siderite concretions

Shale, bluish-black

Limestone shell breccia or coquina, finely sandy, gray, weathering yellowish, abundantly fossiliferous, mainly in the form of shell fragments, but including a few shells with features partly or nearly completely preserved; the fossils described in this paper were obtained from this bed.

Shale, bluish-black

Siderite concretions, platy, dark reddish-brown

Shale, bluish-black -..-_-

Sideritic layer.

Shale, bluish-black

Total

10.0

0.1

4. 0

0.2

3.5

dkins and Lozo estimate that the base of the preceding section as exposed lies about 5 feet above the contact of the Pepper shale with the underlying Grayson marl (formerly Del Rio clay), and that about 10 feet of Pepper shale has been eroded from above the exposed section; this would indicate that the total thickness of the member in this area is approximately 40 feet.

The fossils here described were obtained by careful preparation from pieces of the coquina limestone hastily collected during a short stop of the field party at Haunted Hill. It may be assumed that the possibilities of the fauna obtainable from this source were by no means exhausted. The following genera and species were identified from the coquina bed:

\section{Molluscan fossils identified from coquina limestone in Pepper} shale at Haunted Hill, McLennan County, Texas

[*Indicates previously described Woodbine species]

Pelecypoda :

Breviarca (Sanoarca) spiritalis, n. sp.

B. (S.) calciana, n. sp.

Ostrea sp.

Exogyra aquillana, n. sp.

*Anomia ponticulana Stephenson?

*Fulpia pinguis Stephenson

* Cyprimeria patella Stephenson

Cyclorisma nodana, $\mathrm{n}$. sp.

Sinonia lozoi, n. sp.

*"Corbula" hillensis (Stephenson)

Parmicorbula? moodiana, n. sp.

Gastropoda :

Turritella shuleri pepperana, $\mathrm{n}$. var. Anchura umbrana, n. sp.

Cephalopoda :

Baculites sp. (cf. B. gracilis Shumard)

Ammonoid fragment (may be Acanthoceras Neumayr or Metoicoceras Hyatt)
The molluscan fauna from the Pepper shale at tho Haunted Hill locality, as listed above, seems to afford clear confirmatory evidence of the Woodbine age of t] ? shale. The four previously described species, marked with an asterisk $\left({ }^{*}\right)$, are all recorded from the Woodbine, and all the genera to which the new species (ard one variety) are assigned are common to that formation. Of these, Breviarca (Sanoarca) and Sinonia seem e:pecially significant as they are known only from tha Woodbine. The new species, Exogyra aquillana, previously described as Exogyra sp., and "Corbula" hillensis (Stephenson), are recorded from the Lewisville merber of the Woodbine, in southern Hill County in beds that are considered by Adkins and Lozo to be Woodbine representatives of the Pepper shale. Two previously described species, Anomia ponticulana and Fulpia pinguis, range throughout the Woodbine. The ammonite genus Baculites Lamarck has not heretofore been recorded from the Woodbine. The only previously d:scribed species in the list, restricted to the Lewisville member of the Woodbine is "Corbula" hillensis (Stephenson ), but the list affords no evidence opposed to tl ? Lewisville age of the Pepper units.

The new forms here described constitute additions to the fauna of the Woodbine formation recorded in my recent monograph (U. S. Geol. Survey Prof. Paper 242 ), and the present paper may be considered a supplement to it.

\section{SYSTEMATIC DESCRIPTIONS}

Class PELECYPodA

Order PRIONODESMACEA

Family ARCIDAE

Genus BREviaRCA Conrad, 1872

Subgenus SANOARCA Stephenson, 1953

Breviarca (Sanoarca) spiritalis Stephenson, n. sp.

Plat 13, flgures 1, 2

Shell small, subtrapezoidal in outline, strongly inflated centrally, inequilaterial, subequivalve. Umbonal ridge distinct, subangular, a little rounded at the angle. Posterodorsal slope steeply descending, broadly exc?vated. Beaks prominent, strongly incurved, slightly opisthogyrate, situated slightly in advance of the midlength. Anterior margin forming an obtuse subangle with the forward end of the area, regularly rounded below; ventral margin broadly rounded; posterior margin obtusely subangular below at end of umbonal ridge, nearly straight to slightly convex and inclined forward above, meeting the hinge line at an obtuse angle. Surface bears raised concentric lines that b?come stronger near the margins, and obscure radiating 
lirae that also become a little stronger near the margins, especially on the dorsal slopes.

Dimensions of the holotype, a right valve: Length $9.1 \mathrm{~mm}$, height $6.4 \mathrm{~mm}$, convexity about $3 \mathrm{~mm}$.

Area long, subtriangular, straight on lower edge, apparently smooth; because ligamental cross striations seem to be absent, the species is referred to the subgenus Sanoarca Stephenson. Hinge long, narrow, straight on upper edge, widening a little and arching down slightly toward each end; teeth numerous, not sharply preserved, transverse centrally, becoming slightly oblique toward the ends of the hinge. Inner surface not uncovered.

Breviarca (Sanoarca) faucana Stephenson, is of comparable size, but the present species is longer in proportion to height, and has a much longer, straighter and more delicate hinge. Breviarca $(S$.) faucana is recorded from the Euless and Lewisville members of the Woodbine formation. The abundant $B$. (S.) habita Stephenson resembles $B$. (S.) spiritalis in shape but is smaller and has sharper concentric and radiating lirae. Breviarca (S.) calciana, n. sp., is more elongated, more sharply pointed posteriorly, has a stronger development of concentric growth ridges, and more obscure radiating lines.

Types.-Holotype, U.S.N.M. 108336; 15 unfigured paratypes, U.S.N.M. 108337; all from the Pepper shale member of the Woodbine formation, at the Haunted Hill locality.

Breviarca (Sanoarca) calciana Stephenson, n. sp.

Plate 13, figures 3, 4

Shell small, elongate-subtrapezoidal in outline, inflated, inequilateral, subequivalve, broad in umbonal region; umbonal ridge long, subangular, concave upward in trend; posterodorsal slope long, descending, broadly excavated, deepest near and parallel to the umbonal ridge; beaks moderately prominent, incurved, slightly opisthogyrate, situated about two-fifths the length from the anterior end; anterior margin regularly rounded, ventral margin very broadly rounded, posterior extremity rather sharply subangular at end of umbonal ridge, posterior margin nearly straight to slightly convex, inclined strongly forward, meeting the hinge line at a wide obtuse angle. Surface smooth in the umbonal region, but away from the beak the growth lines increase in coarseness and toward the margins form round-crested growth ridges spaced about four to the millimeter radially.

Dimensions of the holotype, a left valve: Length $\mathbf{1 1 . 6}$ $\mathrm{mm}$, height $7.3 \mathrm{~mm}$, convexity $3.5 \mathrm{~mm}$.

Area greatly elongated, subtriangular, apparently smooth, showing neither transverse nor chevron-shaped ligamental grooves. Hinge long, narrow, straight on upper edge, widening slightly and arching down a little at the ends; teeth numerous, central oras transverse, those on the wider ends slightly oblique.

This species resembles Breviarca (Sanoarea) spiritalis in size but is more elongated, more sharply pointed at the posterior end, has a coarser development of concentric growth ridges toward the margins, and has practically no radial sculpture.

Ty.pes.-Holotype, a left valve, U.S.N.M. 108338; 1 figured paratype, U.S.N.M. 108339; 10 unfigured paratypes, U.S.N.M. 108340.

\section{Superfamily OSTRACEA \\ Family OSTREIDAE \\ Genus OSTREA Linné, 1758 \\ Ostrea sp.}

Two small water-worn specimens of Ostrea Linné are present in the collection from Haunted Hill. One of them is subcircular in outline, relatively thick and measures $10 \mathrm{~mm}$ in length. The other is subovate in outline, shows the hinge rather obscurely, and is $13 \mathrm{~mm}$ long and $15 \mathrm{~mm}$ high. These may be young examples of Ostrea soleniscus Meek, a common species in the Woodbine formation. U.S.N.M. 108341.

Genus EXOGYRA Say, 1820

Exogyra aquillana Stephenson, n. sp.

Plate 13, figures 5-8

Exogyra sp. Stephenson, U. S. Geol. Survey Prof. Paper 242, p. 78, pl. 18, figs. 4-6, 1953.

This species was described and figured without a specific name, as indicated above. The shells, which are present in great numbers at the Aquilla Creek locality, were thought to be a depauperate assemblage of some larger species. Four shells found at the. Haunted Hill locality seem to be conspecific with tha Aquilla Creek shells, and to indicate that the species has a rather wide geographic range, and is of value as an index fossil. It seems desirable therefore for convenience of reference to give it a specific name. The available material includes only left valves. One internal mold of a small Exogyra in a matrix of ferruginous sandstone of the Euless member of the Woodbine formation on State Highway 183, withir 1.2 miles west-southwest of Euless, Tarrant County, Texas (U.S.N.M. 105227), probably belongs to this species. This specimen was described, but not figured, on page 78 of Professional Paper 242.

The largest specimen (a paratype) measures about $23 \mathrm{~mm}$ in its greatest dimension (height). Most of the 
shells are less than $17 \mathrm{~mm}$ in height. The shells are smooth, strongly convex, and narrow in the umbonal region. The beak is sharply twisted at the tip except as it may be modified by the scar of attachment. The shells show individual variations in form. The specimens consist of internal molds to which some shell substances adheres.

Dimensions of the holotype : Length $11 \mathrm{~mm}$, height 15 $\mathrm{mm}$, convexity $6 \mathrm{~mm}$.

The adductor scar as seen impressed on the internal mold of one paratype is of moderate size, subcircular, situated a little below midheight and a little back of midlength.

Types.-Holotype, U.S.N.M. 105225a ; 1 figured paratype, U.S.N.M. 105225b; 53 unfigured paratypes, U.S.N.M. 105226; all from Aquilla Creek at base of Lewisville member of Woodbine formation, 1.2 miles east of Aquilla, Hill County, Texas (U.S.G.S. Coll. 19018). One figured paratype, U.S.N.M. 108342; 3 unfigured paratypes, U.S.N.M. 108343; from the Pepper shale member of the Woodbine formation, 11 feet above base, at Haunted Hill, on the Paul Alexander farm, about $3 \frac{1}{2}$ miles northwest of Moody, McLennan County, Texas (U.S.G.S. Coll. 23634). One unfigured paratype, U.S.N.M. 105227; from Euless member of Woodbine formation on State Highway 183, within 1.2 miles west-southwest of Euless, Tarrant County, Texas (U.S.G.S. Coll. 19040).

\section{Superfamily ANOMIACEA \\ Family aNOMIIDAE \\ Genus ANomia (Linné, 1758) Müller, 1776}

Anomia ponticulana Stephenson?

Anomia ponticulana Stephenson, U. S. Geol. Survey Prof. Paper 242 , p. 81, pl. 20, figs. 1-4, 1953.

The Haunted Hill locality yielded six small poorly preserved specimens of Anomia that probably belong to $A$. ponticulana Stephenson. The typical fine radiating lirae of that species are wanting, but the outer shell layer of the specimens appears to have been worn or peeled off before preservation. Besides, even on the typical shells, the radiating lirae are usually obscure or wanting and the largest of these six specimens is only $12 \mathrm{~mm}$ in length. They show some variations in form, but all are subcircular left valves of low convexity. U.S.N.M. 108344.

\section{Order TELEODESMACEA}

Superfamily CYRENACEA

Family CYRENIDAE

Genus FULPIA Stephenson, 1946

Fulpia pinguis Stephenson

Fulpia pinguis Stephenson, Jour. Paleontology, vol. 20, No. 1, p. 68, figs. 1-4, 1946.

Fulpia pinguis Stephenson, U. S. Geol. Survey Prof. Paper 242, p. 97, pl. 23, figs. 1-4, 1953.

Fulpia pinguis Stephenson is represented in the Haunted Hill collection by 5 poorly preserved knt identifiable specimens. The shape, surface features, and characters of the partly preserved right and left hinges agree well with the types from the Lewisville memk or of the Woodbine formation on Sheep Creek in Fanrin County, Texas. The largest specimen from Haunted Hill, a left valve, measures: Length about $24 \mathrm{~mm}$, height about $21.5 \mathrm{~mm}$, convexity about $9.5 \mathrm{~mm}$. The species ranges throughout the full thickness of the Woodbine formation. U.S.N.M. 108345.

\section{Superfamily VENERACEA \\ Family VENERIDAE \\ Genus CYPRIMERIA Conrad, 1864 \\ Cyprimeria patella Stephenson}

Cyprimeria patella Stephenson, U. S. Geol. Survey Prof. Paper 242, p. 108, pl. 27, figs. 12-18, 1953.

The collection from Haunted Hill includes 11 poorly preserved, and in part incomplete, specimens of $C y p^{m} \dot{p}$ meria patella Stephenson, 4 right valves, 6 left valv's, and one small shell with both valves intact. These specimens range from $8.5 \mathrm{~mm}$ to about $40 \mathrm{~mm}$ in leng $\mathrm{g}^{\mathrm{h}} \mathrm{h}$. The holotype, a shell $52 \mathrm{~mm}$ long is from the Templeton member of the Woodbine formation near old Slate Shoals on Red River, 8 miles east of Arthur City, Lamar County, Texas. The shells from Haunted Hill do $\mathrm{r}$ t differ from the types in any essential feature. The species is not recorded from the Lewisville member of the Woodbine formation, with which the Pepper shale has been correlated. U.S.N.M. 108346.

\section{Genus CYCLORISMA Dall, 1902}

Cyclorisma nodana Stephenson, n. sp.

Plate 13, figures 9-12

This is a common species at Haunted Hill, though, as is usually true of fossil shells in coquina, most of the 
specimens are poorly preserved. Several of them are in fair condition.

Shell small, thin, subcircular in outline, slightly inequilateral, equivalve, moderately convex, greatest inflation above the midheight. Beaks rather prominent, incurved, prosogyrate, approximate, situated a little in advance of the midlength. Lunule not excavated but distinctly outlined by a narrow groove; escutcheon wanting. Surface with numerous, regularly spaced, round crested, concentric ribs, numbering 4 to the millimeter in the radial direction on the adult stage.

Dimensions of the holotype, a left valve: Length 13 $\mathrm{mm}$, height $12.5 \mathrm{~mm}$, convexity $5 \mathrm{~mm}$. The largest specimen in the collection is about $15 \mathrm{~mm}$ long.

Ligament external, about $4.5 \mathrm{~mm}$ long in the holotype; ligamental groove sharply incised, nymph narrow, plain. Hinge with three cardinal teeth in each valve; lower margin of hinge sinuous, convex inward below the beak, concave outward back of the beak; laterals wanting. The cardinal teeth are not very sharply preserved in available material. In the right valve the anterior cardinal tooth is small, short, oblique forward; middle tooth nearly direct inward, apparently thick, probably covered with secondary calcite; posterior tooth oblique rearward, long, subtrigonal, probably bifid; anterior and middle teeth separated by a narrow, deep socket, and middle and posterior teeth by a long oblique trigonal socket of moderate depth. In the left valve the anterior and middle cardinal teeth unite at the top to form an inverted $\mathbf{V}$ the limbs of which are separated by a trigonal socket; the posterior tooth is long, narrow, and very oblique and is separated from the middle tooth by a long, wide, oblique, trigonal socket. The pallial line is well back from the margin and the pallial sinus, as obscurely seen on the internal mold of one of the paratypes, is $\mathbf{V}$-shaped, moderately deep, and points toward the beak.

In form and in hinge characters this species is very much like the genotype, Cyclorisma carolinensis (Conrad), from the Snow Hill marl member of the Black Creek formation at Snow Hill, North Carolina, but the individuals average one-third or less in size.

This species resembles Cyclorisma orbiculata Stephenson from the Templeton member of the Woodbine formation in Lamar County, Texas, and is about the same size, but it is proportionately a little longer; the concentric surface ridges are stronger and more regular, and a lunule is present, outlined by a distinctly impressed line. Specimens that have the hinge covered or missing might easily be mistaken for a representative of the genus Fulpia Stephenson.
Types.-Holotype, U.S.N.M. 108347 ; 2 figur - d paratypes, U.S.N.M. 108348; 20 unfigured paratypes, U.S.N.M. 108349.

\section{Genus SINONIA Stephenson, 1953}

Sinonia lozoi Stephenson, n. sp.

Plate 13, figures 13-15

This species is represented in the collectior. by one apparently adult left valve whose margin is broken away in places, and by four fragments of young individuals, two left and two right valves, all with beaks preserved; the large left valve (holotype) is complete enough to show outline, form, surface features, and hinge. One fragment, a right valve, shows a nearly complete, partly worn hinge.

Shell of medium size, subovate-elongate in outline, thin, compressed, strongly inequilateral, equivalve. Beaks moderately prominent, incurved, prosogyrate, situated about one-third the length of the sholl from the anterior end. Lunule and escutcheon wanting. Anterodorsal margin steeply descending, broadly arched; anterior margin rounded less than a semicircle; ventral margin very broadly rounded; posterior margin less sharply rounded than the anterior margin, fullest below, slightly subtruncate in the adult; posterodorsal margin long, broadly arched, gently descending. Surface showing only unequally developed incremental lines and low, narrow, irregular ridges.

Dimensions of the holotype: Length $32.5 \mathrm{~mm}$, height about $23 \mathrm{~mm}$, convexity about $6.5 \mathrm{~mm}$.

Ligament external, opisthodetic, groove narrow, deeply impressed, nymphs long, narrow, and rather prominent. Three cardinal teeth in left valve; anterior and median cardinals about equal in size and joined at upper ends to form an inverted $\mathbf{V}$ inclosing a deep trigonal socket; anterior cardinal strong, slightly bifid, directed inward and slightly forward; middle tooth simple, directed inward and slightly backwarl; posterior tooth long, strongly oblique rearward peralleling the nymph, weak, separated from the middle cardinal by a long, wide, and deep trigonal socket; in front of the anterior cardinal is a moderately deep trigonal socket opening into a shallow lateral channel that extends forward about $5 \mathrm{~mm}$. Features of the inner surface not uncovered. The hinge of the right valve is nearly complete in a shell fragment that shows somewhat worn nymph and teeth. The anterior cardinal tooth is of medium strength and is separated from a strong trigonal middle tooth by a narrow deep socket; the posterior cardinal tooth is long, narrew, bifid, strongly oblique; it is separated from the middle tooth by a long, narrow, trigonal, oblique socket and from the nymph by a long, narrow socket. 
Although the holotype of this species is about the size of the holotype of Sinonia levis Stephenson (the type species of the genus, from the Woodbine formation), the former is higher in proportion to the length, has a heavier hinge plate, a slightly longer ligament, and a somewhat more prominent umbonal region.

Types.-Holotype, U.S.N.M. 108350; 1 figured paratype, U.S.N.M. 108351; 3 unfigured paratypes, U.S. N.M. 108352. Named in honor of Frank E. Lozo.

Superfamily MYACEA

Family CORBULIDAE

Genus CORBULA Lamarck, 1799

"Corbula" hillensis (Stephenson)

Plate 13, figures $16-20$

Parmicorbula? hillensis Stephenson, U. S. Geol. Survey Prof. Paper 242, p. 133, pl. 33, figs. 13-15, 1953.

The holotype and paratypes of this species are internal and external molds in fine ferruginous sandstone from a roadside exposure 3 miles northeast of Whitney, Hill County, Texas; the collection was made by Roy $T$. Hazzard about 1941. The species is represented at the Haunted Hill locality by many shells, mostly worn or incomplete, but a few are nearly complete and show the form, surface features, and hinges with only minor defects. Both right and left valves are present, but the two valves are not found together as one individual. No features indicating the presence of an accessory siphonal plate back of the terminus of the left valve can be detected in any of the shells, for which reason the species is here treated as belonging to "Corbula", as this name is used in a broad sense; it falls definitely within the family Corbulidae. The species is here redescribed on the basis of the more complete specimens now available.

Shell of medium size, subtrigonal in outline, strongly inflated in the umbonal and anterior parts, narrow and strongly constricted in the posterior part, inequilateral, inequivalve. Beaks very prominent, incurved, prosogyrate, situated a little in advance of the midlength on the right valve, nearly central on the left valve; right valve more strongly inflated than the left and beak more strongly incurved. Anterodorsal margin steeply descending, broadly arched; anterior margin sharply rounded below the midheight; ventral margin broadly rounded becoming slightly concave near the posterior extremity; posterior margin short, subtruncated, inclined slightly forward; posterodorsal margin gently inclined, nearly straight or slightly sinuous. Surface of right valve covered with pronounced, irregular concentric ribs that increase in coarseness outward toward the margins; these ribs end rearward a little short of the posterodorsal slope. Surface of left valve nearly smooth, or with weakly and irregularly developed concentric ribs.

Dimensions of the plesiotype (right valve) shown in plate 13, figure 20 : Length $13.1 \mathrm{~mm}$, height $9 \mathrm{~mm}$, convexity $4.5 \mathrm{~mm}$.

Hinge of right valve with one cardinal tooth of medium size below the beak; back of the tooth is a desp resiliary pit; in one plesiotype the tooth appears to be somewhat worn. Hinge of left valve has a rathor short, somewhat worn resiliary platform which is directed obliquely rearward and slopes steeply forward toward a deep trigonal cardinal socket. Internal molds show that the anterior adductor scar is small and subovate, and the posterior adductor small, elongate, and seated on a raised platform.

T'ypes.-Holotype, U.S.N.M. 105555; paratypes, U.S.N.M. 105556 (figured) and 105557. Plesiotyres from the Haunted Hill locality (U.S.G.S. Coll. 23634; U.S.N.M. 108353a-c); numerous unfigured examples from Haunted Hill, U.S.N.M. 108354.

Occurrence.-Holotype and paratypes, northeastsouthwest road, 3 miles northeast of Whitney, Hill County (U.S.G.S. Coll. 19020). Three plesiotypes and numerous other specimens from Haunted Hill, $3 \frac{1}{2}$ miles northwest of Moody, McLennan County (U.S.G.S. Coll. 23634). Ravine east of road to Gholson, 2.8 miles east of Gholson (U.S.G.S. Coll. 1458"), and Elm Creek, 2 miles southwest of Wiggins, 6.5 miles southwest of the town of West, McLennan County (U.S.G.S. Coll. 23635).

\section{Genus PARMICORBULA Vokes, 1944}

Parmicorbula? moodiana Stephenson, n. sp.

Plate 13, figures 21-23

Shell small, subtrigonal in outline, strongly inflated in the umbonal area, narrowing and becoming strongly constricted posteriorly, inequilateral, inequivalve. The posterodorsal slope forms a broadly excavated band crossed only by growth lines, bounded by a subangular umbonal ridge, and extending radially to the truncated terminus. Beaks very prominent, incurved, prosogyrate, situated at or a little anterior of the midleng ${ }^{2} h$. Anterodorsal and anterior margin rather sharr'y rounded below the midheight; ventral margin broacly rounded. Posterior margin of right valve short, trincated, inclined forward, meeting the posterodorsal margin at an obtuse angle; the latter margin gently inclined, nearly straight or a little upturned at the rear. Posterior margin of left valve bluntly subangular below the midheight, rounding upward into the posterodorsal margin. The two valves were not seen together but the 
narrow, flattish, posterior extension of the right valve, compared with the shorter blunt extremity of the left valve suggest that there was in the living shell an accessory siphonal plate at the terminus of the latter; this plate would be lost when the two valves became separated. The existence of this plate is also suggested by the presence of a radial groove on the outer surface of the posterior extension of the right valve, possibly reflecting a radial ridge on the inner side of this extension; on the typical Parmicorbula a ridge of this sort on the inner side of a posterior projection stands opposite a similar ridge on the inner side of the characteristic accessory plate, the function of the two ridges being to separate the two siphons where they pass out rearward. On the right valve the umbonal part of the outer surface, including one-third to one-half the total surface, is smooth; the rest of the surface in front of the umbonal ridge is covered with small, closely spaced concentric ridges, which increase in coarseness toward the outer margin, where they number 3 or 4 to the millimeter in the radial direction. The surface of the left valve shows only obscure growth ridges interrupted on some shells by an occasional groove marking a resting stage in growth.

Dimensions of the holotype, a right valve: Length 5 $\mathrm{mm}$, height $3.6 \mathrm{~mm}$, convexity about $1.5 \mathrm{~mm}$. A larger right valve (a paratype) measures: Length about 5.5 $\mathrm{mm}$, height $4 \mathrm{~mm}$, convexity about $2 \mathrm{~mm}$. The left valve is slightly shorter than the right.

Hinges and internal features not well enough uncovered for description.

The species resembles Parmicorbula corneliana Stephenson, but it is smaller, not quite so plump, and less coarsely sculptured.

Types.-Holotype, a right valve, U.S.N.M. 108355 ; 2 figured paratypes, U.S.N.M. 108356; unfigured paratypes, 3 left valves and 5 right valves, U.S.N.M. 108357.

\section{Class Gastropoda}

Order CTENOBRANCHIATA

Family TURRITELIIDAE

Genus TURRITELLA Lamarck, 1799

Turritella shuleri pepperana Stephenson, n. var.

Plate 13, figure 24

The coquina limestone in the Pepper shale at Haunted Hill yielded several fragmentary specimens of a noded form of Turritella Lamarck, representing early stages of growth, all poorly or incompletely preserved. They are closely related to $T$. shuleri Stephenson from the Lewisville and Templeton members of the Woodbine formation and are here treated as a variety of that species. The shells show some variation in details of sculpture, but the description is based mainly on the holotype.

The shell is high-turreted; the sides of the whorls are nearly flat and are separated by a moderately deep sutural depression. Each whorl bears 4 primary noded spirals; the uppermost primary is the smallest of the four and bears the most numerous small, closely spaced nodes; the second primary below the suture is largest and bears the coarsest and most prominent nodes; the two lowest primaries are of about equal strength and bear nodes of intermediate size and prominence. Between the second and third primary below the suture is a rib of medium strength that may be clarsed as a secondary spiral; it is neatly ornamented witl numerous, small beadlike nodes; between the lcwermost primary and the lower suture are two nearly smooth spirals of about secondary strength. All the other intermediate primaries are very small (tertiaries) and are more or less clearly ornamented with very tiny nodes; they number one to three in the interspaces between the primaries and secondaries. The poriphery is subangular and the flatttish base is covered with fine, rather obscure spiral lirae. The diameter of the largest whorl of the holotype is $6 \mathrm{~mm}$.

Because of the individual differences in the spiral sculpture of the typical Turritella shuleri the sculpture of this variety cannot satisfactorily be compared with it in detail; in general, however, the former possesses thicker and stronger primary spirals, and these spirals bear much coarser nodes, especially the two upper ones, than is true of the latter at the same stage of growth. Compared with the typical $T$. shuleri the base of this variety appears to be flatter, the periphery more angular, and the suture a little more deeply impress ?d.

Types.-Holotype U.S.N.M. 108358; 10 unfigured paratypes, U.S.N.M. 108359.

\section{Family APORRHAIDAE \\ Genus ANCHORA Conrad, 1860}

Anchura umbrana Stephenson, n. sp.

Plate 13, figures 25-30

Shell rather small for the genus, high-turreted, with spiral angle of about 30 degrees. Protoconch not preserved. Whorls 6 or 7 , gently convex on the side, the larger whorls ornamented with axial ribs and spiral lirae; on the penultimate whorl the axials are small, closely crowded, and number at least 22 ; they are strongly oblique and sinuous in trend, being slightly convex forward below, broadly concave forward above, bending strongly forward just below the suture; the spirals are small, obscure centrally, and become a little stronger toward the sutures both below and atove. On 
the body whorl the axials extend well down the basal slope, becoming weaker toward the lip; they are broadly convex forward in trend except near their upper ends where they bend forward to the suture. The spirals are obscure on the inflated part of the body whorl but become stronger above, the uppermost just below the suture being relatively coarse; about 10 spirals are present on the basal slope, the upper 4 or 5 being weak to obscure, and the lower 5 or 6 relatively strong; low rounded nodes mark the intersections of the axials with the stronger spirals. The aperture is ovate-elongate. The outer lip is expanded and winglike but is poorly preserved in the available material. A rather obscure impression on one paratype (pl. 13, fig. 29), and one wing broken from its parent shell (pl. 13, fig. 30) indicate the presence of one thick, winglike, upturned projection; the latter figure shows the interior of the broken wing. The inner lip forms a rather broad band of callus over the parietal wall.

Dimensions of the holotype, an. incomplete shell: Diameter, exclusive of the expanded lip, about $11.5 \mathrm{~mm}$, height $24+\mathrm{mm}$.

Types.-Holotype, U.S.N.M. 108360; 4 figured paratypes, U.S.N.M. $108361 ; 30$ or more unfigured paratypes, mostly poorly preserved, U.S.N.M. 108362.

Order CEPHALOPODA

Family LYTOCERATIDAE

Genus BACULITES Lamarek, 1799

Baculites sp.

Plate 13, figure 31

The genus Baculites Lamarck (sensu lato) is represented in the collection from Haunted Hill by one fragment which apparently pertains to a small smooth slender species having a broadly ovate cross section. The specimen is slightly crushed on one side but its dimensions are approximately as follows: Length $13+\mathrm{mm}$, greatest dorso-ventral diameter $5.8 \mathrm{~mm}$, greatest transverse diameter $5 \mathrm{~mm}$; at the small end the dorso-ventral diameter is about $5 \mathrm{~mm}$ and the transverse diameter about $4.6 \mathrm{~mm}$. Sutures are obscurely recognizable on the crushed side of the fragment where the shell has been partly peeled off, and one incomplete septum is uncovered at the small broken end of the conch. U.S.N.M. 108363.

This short, incomplete specimen of Baculites appears to be smooth, lacking the oblique cross undulations that characterize a similar species common in the Metoicoceras whitei zone in the Eagle Ford shale 50 or 60 feet above its base in Texas. This species from the Eagle Ford formation is usually referred to $B$. gracilis B. F. Shumard, but is now considered by J. B. Reeside, Jr. and others as belonging to the genus Sciponoceras Hyatt. In this connection attention is called to Shumard's statement that his species was found on Shawnee Creek in Grayson County, Texas (1860, p. 596). The only creek by this name shown on present available maps of Grayson County is northwest of Devison in a drainage basin that lies entirely within an area underlain by strata of the Comanche series. Shumerd did not illustrate the species, his type material is presumed to be lost, and an identification can not safely be made from his published description. If the Shawnee Creek on which G. G. Shumard (brother) collected the types of Baculites gracilis is the same as the creek c"rrently known by that name there is reason to doubt tl at the species of Sciponoceras associated with Metoicoceras whitei Hyatt in the stratigraphically higher Eagle Ford shale is correctly referable to Baculites gracilis Sl umard; it probably needs a new specific name.

No representatives of Baculites are recorded in my recent (1953) treatise on the larger invertebrate fossils of the Woodbine formation of Texas. Adkins (19?0, p. 74) describes a species, Baculites comanchensis, from the Pawpaw formation (upper part of Comanche series), near Fort Worth, Texas. This species he later referred tentatively to Cyrtochilus Meek (1928, p. 207). This is about the lower limit of the known stratigraphic range of Baculites (sensu lato).

\section{Family COSMOCERATIDAE?}

Genus?

\section{Ammonoid fragment (Acanthoceras? or Metoicoceras?)}

The coquina bed at Haunted Hill yielded one small scarcely identifiable ammonoid fragment that may belong to the genus Acanthoceras Neumayr, or possibly to Metoicoceras Hyatt. The specimen shows two lateral radiating ribs, each with a fairly high elongated node on the umbilical shoulder; between these two ribs is part of a shorter rib, and part of another short rib appears to the left of the three ribs. U.S.N.M. 108364.

\section{REFERENCES}

Adkins, W. S., 1920, The Weno and Pawpaw formations of the Texas Comanchean: Texas Univ. Bull. 1856.

1928, Handbook of Texas Cretaceous fossils : Texas Univ. Bull. 2838.

1933, The geology of Texas; Pt. 2, The Mesozoic systemas in Texas: Texas Univ. Bull. 3232, pp. 239-518.

- and Lozo, F. E., 1951, Stratigraphy of the Woodbine and Eagle Ford, Waco area, Texas, in Adkins, W. S., and others, 1951, The Woodbine and adjacent strata of the Waco area of central Texas: Fondren Science Series 4 (Dallas), pp. 101-164, 6 pls.

Loeblich, A. R., Jr., 1946, Foraminifera from the Pepper stale of Texas: Jour. Paleontology, vol. 20, no. 2, pp. 130-1.39, pl. 22, 3 figs. 
Lozo, F. E., 1951, Stratigraphy of the Woodbine and Eagle Ford, Waco area, Texas, in Adkins, W. S., and others, 1951, Stratigraphic notes on the Maness (Comanche Cretaceous) shale: Fondren Science Ser. 4 (Dallas), pp. 65-92, 7 figs. 2 pls.

Plummer, Helen Jeanne, 1933, cited in Adkins, W. S., The geology of Texas; Pt. 2, The Mesozoic systems in Texas: Texas Univ. Bull 3232, pp. 419-420.
Shumard, B. F., 1860, Descriptions of new Cretaceo"s fossils from Texas: Acad. Sci. St. Louis Trans., vol. 1, pr. 590-610. Stephenson, L. W., 1927, Notes on the stratigraphy of the Upper Cretaceous formations of Texas and Arkansas: Am. Assoc. Petroleum Geologists Bull., vol. 11, no. 1, pp. 1-17.

1953, Larger invertebrate fossils of the Woodbine formation (Cenomanian) of Texas: U. S. Geol. Survey Prof. Paper 242. 


\section{N DEX}

[Italic numbers indicate descriptions]

\begin{tabular}{|c|c|}
\hline $\mathbf{I}$ & $5 \pi$ \\
\hline soceras, W. S., and Lozo, E. E., quoted & \\
\hline ura umbrana & \\
\hline $\begin{array}{l}\text { nomia ponticulana } \\
\text { luillana, Exogyra. }\end{array}$ & - n-m- \\
\hline $\begin{array}{l}\text { aculites comanchensis___n } \\
\text { gracilis }\end{array}$ & 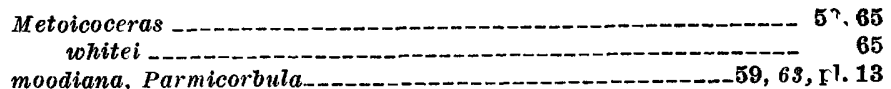 \\
\hline 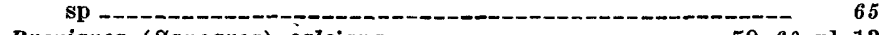 & \\
\hline (Sanoarca) calciana___. &. \\
\hline 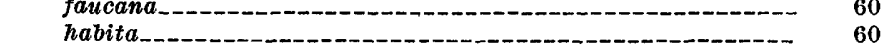 & \\
\hline alis & 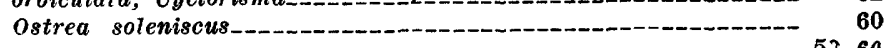 \\
\hline - & \\
\hline risma & -n-n-n-n- \\
\hline 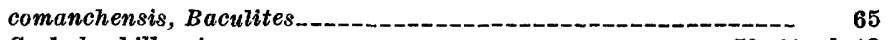 & 59,68, \\
\hline - & 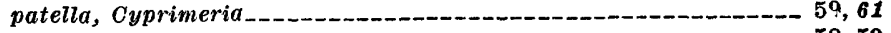 \\
\hline -n-n--n-n--n- & $--m-n-m-n$ \\
\hline ensis & 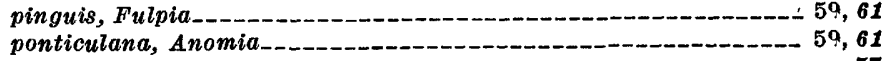 \\
\hline 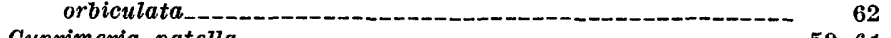 & 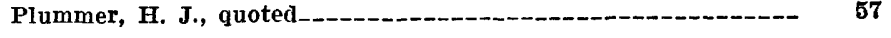 \\
\hline 59,6 & \\
\hline & 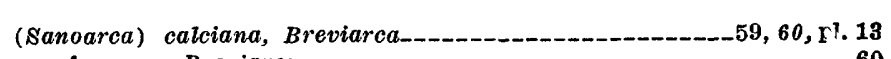 \\
\hline- & - \\
\hline - 59,60, pl. 1 & $59,60, \mathrm{r}^{\top}, 1$ \\
\hline - & - \\
\hline 6 & 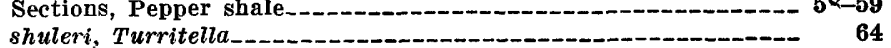 \\
\hline - & 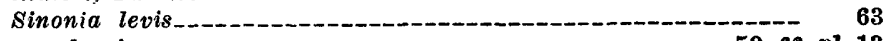 \\
\hline 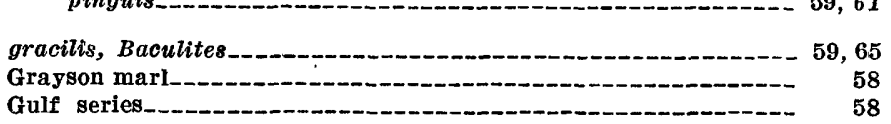 & $\begin{array}{l}\text { lozoi } \\
\text { leniscus, Ostrea } \\
\text { iritalis, Breviarca (Sanoarca) }\end{array}$ \\
\hline -1--1-- & - \\
\hline orbula & nation \\
\hline
\end{tabular}





\section{PLATE 13}




\section{PLATE 13}

[With the exception of the holotype and one paratype of Exogyra aquillana, 1. sp. all the specimens illustrated on this plate are from the Pepper shale at Harnted Hill, McLennan County, Teras, U.S.G.S. coll. 23634]

Figures 1, 2. Breviarca (Sanoarca) spiritalis, n. sp. (p. 59).

Side and dorsal views, $\times 4$, of the holotype (a right valve) U.S.N.M. 108336.

3, 4. Breviarca (Sanoarca) calciana, n. sp. (p. 60).

3. Side view, $\times 4$, of the holótype, (a left valve), U.S.N.M. 108338.

4. Hinge view, $\times 4$, of a paratype, (a left valve), U.S.N.M.108339. The numerous small transverse teeth are only obscurely shown on figure 4 .

5-8. Exogyra aquillana, n. sp. (p. 60).

5, 6. Side and front views, $\times 2$, of the holotype, (a left valve), from Aquilla Creek, 1.2 miles east of Aquilla, Hill County, Texas, U.S.N.M. 105225a. (From U.S.G.S. coll. 19018.)

7. Side view, $\times 2$, of a paratype, (a left valve), from the same source, U.S.N.M. 105225b.

8. Side view, $\times 2$, of a paratype, (a left valve), from the Pepper shale at Haunted Hill, U. S.N.M. 108342.

9-12. Cyclorisma nodana, n. sp. (p. 61).

9, 10. Side and hinge views, $\times 3$, of the holotype, (a left valve), U.S.N.M. 108347.

11,12. Hinge views, $\times 3$, of 2 paratypes, (right and left valves), U.S.N.M. 108348.

13-15. Sinonia lozoi, n. sp. (p. 62).

13, 14. Side and hinge views, $\times 1 \frac{1}{2}$, of the holotype, (a left valve), U.S.N.M. 108350.

15. Incomplete hinge, $\times 3$, of a paratype, (a right valve), U.S.N.M.108351.

16-20. "Corbula" hillensis Stephenson (p. 63).

16, 17. Side and hinge views, $\times 2$, of a plesiotype, (a right valve), U.S.N.M. 108353a.

18, 19 . Side and hinge views, $\times 2$, of a plesiotype, (a left valve), U.S.N.M. 108353b.

20. Side view, $\times 2$, of a plesiotype, (a right valve), U.S.N.M. 108353 c.

21-23. Parmicorbula moodiana, n. sp. (p. 63).

21. Side view, $\times 4$, of the holotype, (a right valve), U.S.N.M. 108355.

22. Side view, $\times 4$, of a paratype, (a right valve), U.S.N.M. 108356.

23. Side view, $\times 4$, of a paratype, (a left valve), U.S.N.M. 108356.

24. Turritella shuleri pepperana, new var. (p. 64).

The holotype, $\times$ 3, U.S.N.M. 108358.

25-30. Anchura umbrana, n. sp. (p. 64).

25, 26. Front and back views, $\times 2$, of the holotype, U.S.N.M. 108360.

27-29. Views, $\times 2$, of 3 paratypes, U.S.N.M. 108361.

30. Interior view, $\times 2$, of an expanded outer lip of a paratype, U.S.N.M. 108361.

31. Baculites sp. (p. 65). A fragment, $\times 2$, showing smooth outer surface, U.S.N.M. 108363. 
GEOLOGICAL SURVEY
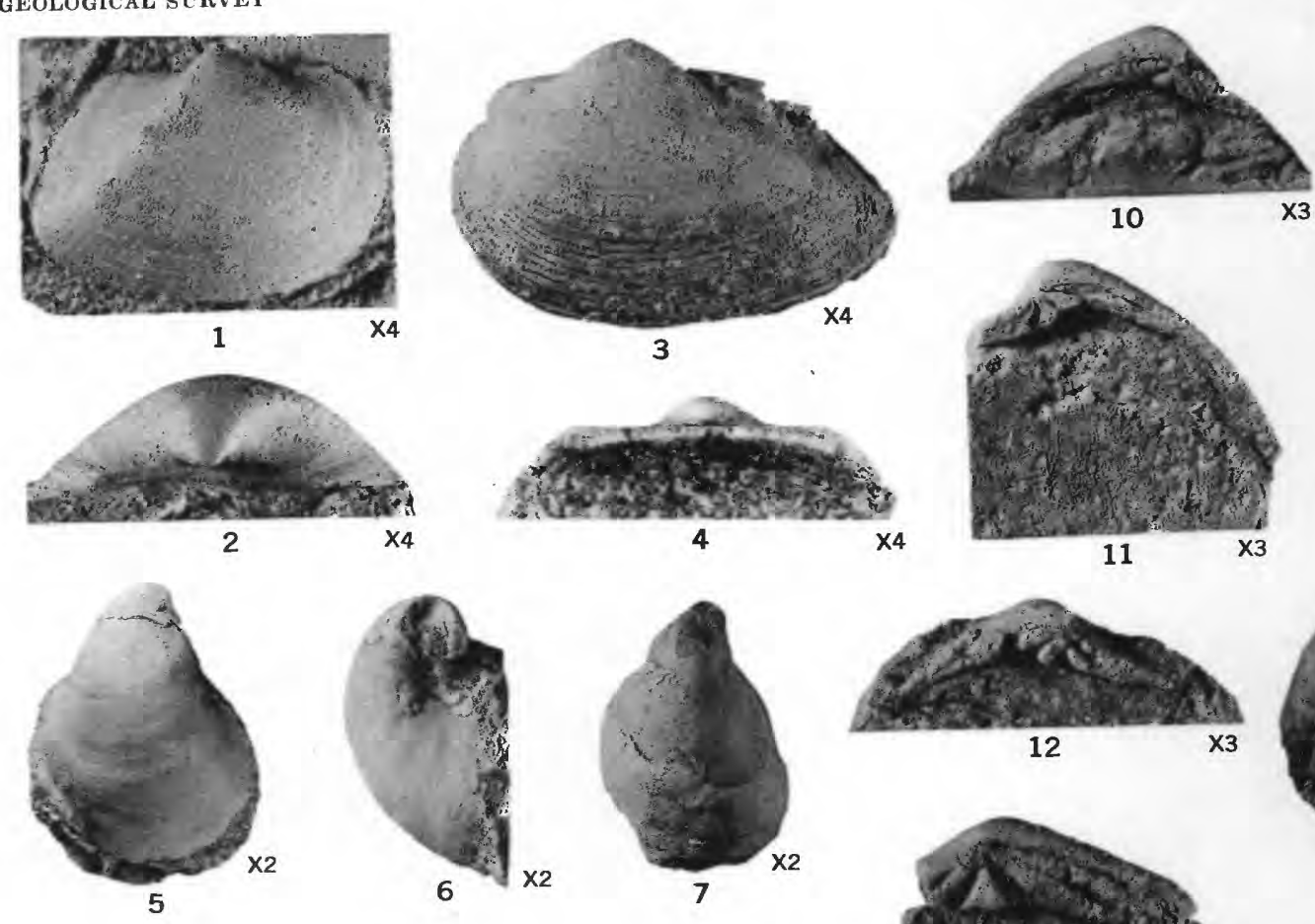

PROFESSIONAL PAPER 243 PLATE 13
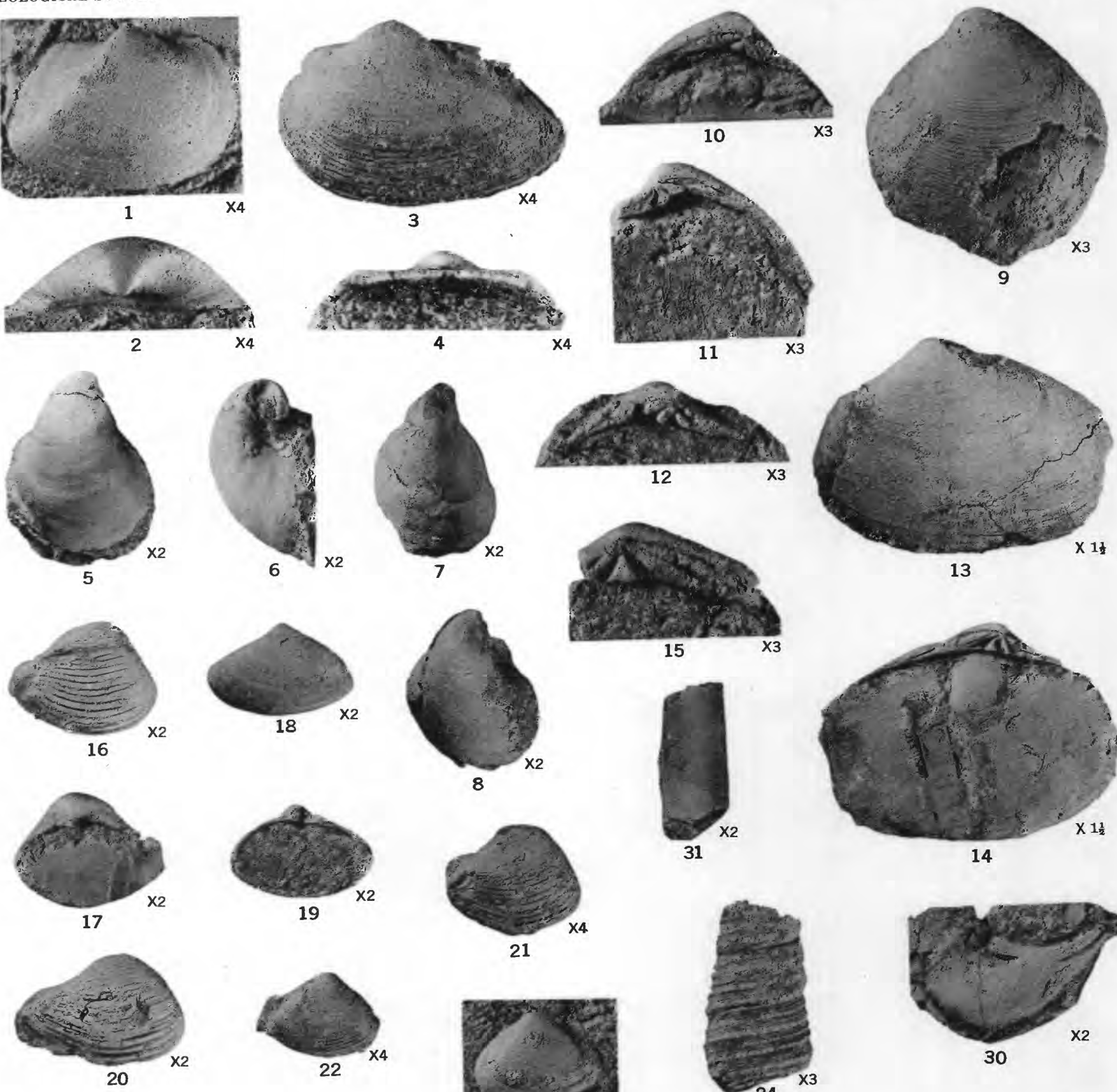
